\title{
A review of the Pteropus rufus (É. Geoffroy, 1803) colonies within the Tolagnaro region of southeast Madagascar - an assessment of neoteric threats and conservation condition
}

\author{
Sam Hyde Roberts', Mark D. Jacobs', Ryan M. Clark!, \\ Charlotte M. Daly", Longosoa H. Tsimijaly"l', Retsiraiky J. \\ Rossizelal', Samuel T. Prettyman'
}

\author{
Correspondence: \\ Sam Hyde Roberts \\ SEED Madagascar, Studio 7, 1A Beethoven Street, \\ London W10 4LG, United Kingdom \\ Email: samhyderoberts@gmail.com
}

\begin{abstract}
We surveyed 10 Pteropus rufus roost sites within the southeastern Anosy Region of Madagascar to provide an update on the areas' known flying fox population and its conservation status. We report on two new colonies from Manambaro and Mandena and provide an account of the colonies first reported and last assessed in 2006. Currently only a solitary roost site receives any formal protection (Berenty) whereas further two colonies rely solely on taboo 'fady' for their security. We found that only two colonies now support an increased number of bats compared with a decade ago, whilst a further two colonies have been either displaced or disturbed and could no longer be found. A single colony appears to have declined significantly whereas a further three coIonies appear to have remained static. In light of a decree that has imposed a specific hunting season for fruit bats, we hope that this census can provide a baseline for future population monitoring and contribute towards the assessment of the effectiveness of the legislation.
\end{abstract}

\section{RÉSUMÉ}

Nous avons suivi 10 dortoirs de renards volants Pteropus rufus dans la région Anosy au sud-est de Madagascar afin de réaliser une mise à jour de l'état de conservation et d'estimer la population de ces chauves-souris dans la région. Notre étude a montré que la densité des colonies dans la région environnante de Tolagnaro était similaire à celle des autres régions du pays. Nous dressons l'état de nos connaissances portant sur deux colonies situées à Manambaro et à Mandela en comparant nos données récentes avec celles de 2006. Un seul dortoir isolé reçoit actuellement une forme de protection formelle, Berenty, et deux autres colonies seulement reçoivent une forme de protection sous la forme de tabous locaux ou «fady ». Nos résultats ont montré que seules deux colonies ont vu leurs effectifs augmenter au cours de la dernière décennie en même temps que deux autres colonies n'ont pas pu être relocalisées, soit parce qu'elles ont disparues, soit parce qu'elles se sont déplacées suite à des dérangements. Les effectifs d'une seule colonie semblent avoir diminué de manière significative tandis que ceux de trois autres colonies semblent avoir été maintenus à leur niveau. Notre étude a montré que l'abondance globale de $P$. rufus dans la région n'a augmenté que d'un pourcent depuis 2006 et que cette augmentation était le résultat de la protection garantie au dortoir dans la réserve privée de Berenty. À la lumière d'un décret qui a imposé une période de chasse spécifique pour les chauves-souris frugivores, nous espérons que ce recensement pourra servir de référence aux futurs programmes de suivi de la population et contribuer à une évaluation de l'efficacité de la législation.

\section{INTRODUCTION}

The endemic Madagascan flying fox (Pteropus rufus) is primarily distributed around the country's periphery, with roosts predominantly found in lowland areas within $100 \mathrm{~km}$ of the coast (Mackinnon et al. 2003, Simmons 2005, Racey et al. 2010). The highest density of roost sites appear to be concentrated in coastal locations (Andriafidison et al. 2008) with only a handful of roosts reported from the central highlands (Mackinnon et al. 2003). In 1999 and 2000 an extensive survey of around a third of the island found only a small number of roost sites within the boundaries of the Anosy Region (Mackinnon et al. 2003). In 2005 a more specific and thorough regional study reported additional $P$. rufus roosts at a further seven localities, bringing the number of known roosts in the region to nine, with a recorded total population of 1,873 individuals (upper estimate) (Jenkins et al. 2007a). The identified roosts were spread throughout the coastal lowlands of the southeast, an area spanning approximately $175 \mathrm{~km}$ and stretching between Marovony in the north and Berenty Private Reserve to the south.

In 2000 an extrapolation based on the survey data obtained across about a third of the island estimated that the national population consisted of approximately 300,000 individuals, and issued the caveat that an estimated $30 \%$ of the population had

\footnotetext{
I SEED Madagascar, Studio 7, 1 A Beethoven Street, London W10 4LG, United Kingdom

III ONG Azafady, Villa Rabemanda, Ambinanikely, BP 318, Tolagnaro 614 (Fort Dauphin), Madagascar

Citation Hyde Roberts, S., Jacobs, M. D., Clark, R. M., Daly, C. M., Tsimijaly, L. H., Rossizela, R. J. and Prettyman, S. T. 2016. A review of the Pteropus rufus (É. Geoffroy, 1803) colonies within the Tolagnaro region of southeast Madagascar - an assessment of neoteric threats and conservation condition. Madagascar Conservation \& Development 11, 1: xx-yy. (doi:10.4314/mcd.v11i1.7) // Early view
} 
been lost over a period of just 20 years (Mackinnon et al. 2003, Andriafidison et al. 2008). The cause of this rapid decline has been well documented (Mackinnon et al. 2003, Andriafidison et al. 2008, Jenkins and Racey 2008) and attributed primarily to a combination of increased hunting pressure and the continual loss of suitable roosting habitat. The chronic degree to which the species is both hunted for bush meat, and persecuted in defense of economically valuable fruit trees (Jenkins and Racey 2008) has also prompted predictions of future declines (Mackinnon et al. 2003, Andriafidison et al. 2008). Unfortunately this pattern of decline is also observable in the other two endemic mega-chiropteran species; the Madagascar straw-coloured fruit bat (Eidolon dupreanum) and the Madagascan rousette (Rousettus madagascariensis), as well as other pteropodid species on western Indian Ocean islands (Nyhagen et al. 2005, Andriafidison et al. 2008, Jenkins and Tatayah 2009, Andrianaivoarivelo et al. 2011).

Forest cover in the Anosy Region appears to have been in a constant state of decline since the first aerial photographs were taken in the early 1950s (Vincelette et al. 2007, Temple et al. 2012). It has been estimated that as much as $90 \%$ of Madagascar's original southern littoral forest has already been lost (Consiglio et al. 2006), with a total of 26,563 ha removed from the Anosy Region alone between 1972 and 2002 (Vincelette et al. 2007). This rapid loss of forest habitat, principally the result of slash and burn agricultural practice (tavy), has severely damaged lowland forest formations (Vincelette et al. 2007) and the pattern continues to this day. Both roosting and foraging sites are hugely threatened by this loss of native forest, a situation exacerbated by the tendency for Pteropus rufus to use small, vulnerable forest remnants outside of protected areas (Jenkins et al. 2007b, Racey et al. 2010). Qualifying the danger from habitat loss alone faced by this species in our specific region of study, a further $80 \%$ of the remaining littoral forests of the Anosy Region are now subject to proposed clearance over the next 50 years, as a result of mining activity and predicted resource use (Temple et al. 2012).

With an ever-increasing body of evidence attesting to the ecological value of Pteropus rufus both as an important pollinator and seed disperser amid highly fragmented landscapes (Bollen and Elsacker. 2002, Mackinnon et al. 2003, Bollen et al. 2004a,b, Nyhagen et al. 2004, Jones et al. 2009, Racey et al. 2010, Shilton et al. 2015), its conservation should now be considered a priority for areas in urgent need of forest regeneration. Further evidence to support the conservation of flying fox roosts, and to encourage the conservation of large colonies stems from the finding that the ecological function attributed to large pteropodid bats, notably seed dispersal, may decline once a population has been reduced to below a threshold size (McConkey and Drake 2006). It is therefore apparent that not only are these keystone species most effective when they are in abundance, but also that their abundance must be monitored and safeguarded.

A decade has now passed since the last comprehensive census of Pteropus rufus was carried out in the southeast Anosy Region (Jenkins et al. 2007a) and since then the legislation governing game animals has been updated (Décret N. 2006-400, Durbin 2007, Racey et al. 2010) in an attempt to reduce hunting pressure and curb declines. These laws now provide bats with some protection in the form of a closed hunting season (2 September-30 April), yet are largely ignored as a result of a widespread lack of recognition and enforcement, rendering them effectively impotent (Jenkins and Racey 2008, Rahaingodrahety et al. 2008). Hunting has played a significant role in recent Madagascan fruit bat declines, with both the proliferation of firearms and erosion of localised taboo or fady cited as responsible factors (Mackinnon et al. 2003, Jenkins and Racey 2008, Jones et al. 2008, Andrianaivoarivelo et al. 2011). Large pteropodid bats are extensively hunted in Madagascar, principally for bushmeat and to protect economically valuable cultivated fruits from predation (Jenkins and Racey 2008). Bats are considered an important source of nutrition, particularly in remote and rural communities, however growing evidence suggests that unsustainable and exploitative practices are becoming more widespread to the evident detriment of multiple species (Andriafidison et al. 2008, Andrianaivoarivelo et al. 2011).

Our study aims to report on the condition of all the known colonies in the southeastern Anosy Region, and provide an update on their local conservation status, and to highlight any persisting or developing threats. During the time of the region's previous population census, flying foxes were considered animaux nuisibles, i.e., pests with hunting permitted without restriction (Mackinnon et al. 2003), and only local fady and cultural sensitivities providing any protection (Jones et al. 2008). Our objective was to observe what impact the 2007 law has had in the area if any, and to reassess the condition of the known flying fox colonies in the southeastern Anosy Region.

\section{METHODS}

Between the months of July and October 2015 a total of 10 roost sites were identified within the borders of the Anosy Region (Figure 1). The roosts were then visited and surveyed by a small team of Malagasy and international researchers. The precise location of each colony was obtained through a combination of local community knowledge and previously cited GPS coordinates (BolIen and Elsacker 2002, Jenkins et al. 2007a, Rahaingodrahety et al. 2008). The survey period was initiated once the breeding season had been concluded (April-June) in order to minimize disturbance, but did however overlap partially with the national open hunting season (Durbin 2007). Our monitoring team consisted of a minimum of two individuals and a maximum of six, including translators. To provide continuity and consistency within the count data, a single researcher (SHR) was present at each survey and responsible for the final count determination.

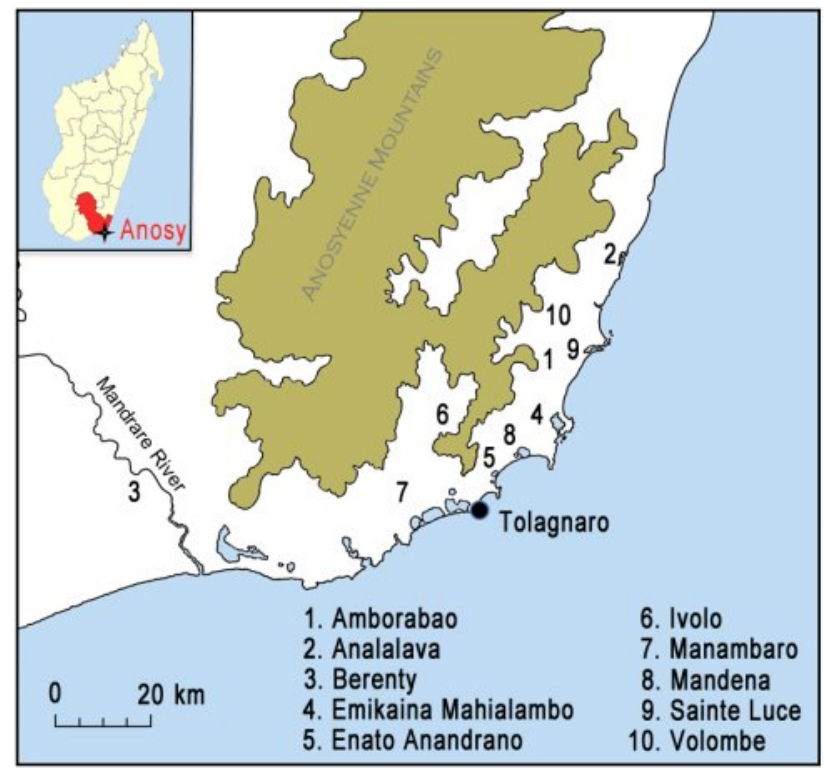

Figure 1. Relative locations of each of the 10 Pteropus rufus roost sites assessed during the study, and their greater position with regards to the island of Madagascar. 
Roost sites were visited in the communes of Amborabao, Analalava, Berenty, Emikaina Mahialambo, Enato Anandrano, Ivolo, Manambaro, Mandena, Sainte Luce and Volombe (Figure 1). On each occasion our visit to the roost was accompanied by either the designated head of the village (chef de fokontany), the local president of VOI (VOI - body responsible for community level resource management) or the president of FIMPIA (a higher tier assembly made up of VOI presidents). During occasions where the roost was situated in sacred forest or in cemetery, permissions were always obtained and the landowner was often hired as our guide. A further roost site previously reported to exist in Marovony (Bollen and Elsacker 2002, Jenkins et al. 2007a) was deemed to be outside of the Anosy Region border and given the lack of detail regarding its location, was not visited. Roost counts and inferred colony size was achieved by counting the individual bats roosting in trees, with roost trees being carefully scanned using binoculars from a suitable vantage point. All surveys were conducted during the daytime, when all bats were expected to be present at the roost. Wherever possible estimates made by several independent observers were obtained and the highest confirmed figure was recorded to guard against accidental underscoring. In addition, wide-angle photographs were taken at all roost sites, and scrutiny of the enlarged images was undertaken to review our results at the site. Similarly, it was often the case that during our assessments, some form of external disturbance caused the colony to take flight and travel to a secondary roost site as a single group. This allowed us to observe the colony in the air, and to film and analyze the footage accurately using basic video tools (Final Cut Pro X).

\section{RESULTS}

Our study indicates that the total abundance of Pteropus rufus in the southeastern Anosy Region stands at approximately 3700 individuals, using conservative estimates collected across the 10 coIonies. At first glance this number appears to have risen significantly from the 1873 individuals recorded in 2006 (Jenkins et al. 2007a), but important caveats must be considered. Firstly this study includes count data from three additional roost sites, Manambaro, Mandena and Berenty Private Reserve, which were not included in the initial 2006 census that we are using as a baseline. This is either because the roosts were not established (Mandena), because their existence was unknown to the researchers (Manambaro) or due to a lack of quantitative data available at that time (Berenty). The combined abundance of these three additional roosts is 2755 bats, substantially more than was previously recorded for the area. Conversely, the total abundance does not include contributions from two roost sites (Enato Ananadrano and Emikaina Mahialambo), as these colonies could no longer be found, and are likely to have either relocated or dispersed. The total number of bats lost from these roosts is not clear, as no historic datasets are available for the colony at Enato Anandrano. However the roost at Emikaina Mahialambo was thought to consist of some 100 bats (Jenkins et al. 2007a).

Of the ten colonies surveyed in this study (Table 1), only two were found to contain over 500 individual bats, (Berenty and Ivolo) and of the extant colonies three were found to support fewer than 200 individuals (Analalava, Sainte Luce and Volombe). The colony present at Berenty Private Reserve is by far the largest colony in the region and supported 2160 bats at the time of its last census in 2013 (J. P. Seccaldu, October 2015, pers. comm.). The colony appears to have increased by approximately 360 individuals between the previous two censuses, conducted in 2011 and 2013 and is known to have stood at between 800 and 1000 individuals in 2001 (Bollen and Elsacker 2002). It is likely that this colony has experienced further growth over the subsequent years. This is the only strictly protected bat colony in the region, and similar increases have not been reflected elsewhere over the same period.

The only other colony in the study besides Berenty to have shown an increased number of bats when compared to the previous count, exceeding the margin for error in estimation, was at the roost situated in Sainte Luce. This colony supported just 104 bats when surveyed in 2006 and now supports approximately 130

Table 1. GPS position (latitude/longitude) of roost sites. (Habitat extents were mapped using a handheld Garmin 62 sc device and determined using Google Earth Pro.; Information regarding the present flying fox populations in Berenty Private Reserve was ascertained through personal communication with long-term forest guide Jean Philipe Seccaldu)

\begin{tabular}{|c|c|c|c|c|c|c|c|}
\hline Location & Survey date & \begin{tabular}{|c|} 
Population \\
estimate
\end{tabular} & $\begin{array}{c}\text { Habitat } \\
\text { extent (ha) }\end{array}$ & Forest type & $\begin{array}{c}\text { Roost } \\
\text { protection }\end{array}$ & Major threat & GPS \\
\hline Amborabao & 09/22/2015 & $338 \pm 15$ & 4.38 & Sacred forest & Yes & Disturbance & E04701'55.81", S24º9'03.58" \\
\hline Analalava & 09/30/2015 & $140 \pm 25$ & 21 & Littoral forest & No & Deforestation & 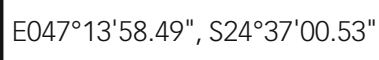 \\
\hline $\begin{array}{c}\begin{array}{c}\text { Berenty Private } \\
\text { Reserve }\end{array} \\
\end{array}$ & 07/06/2015 & 2165 & 177 & $\begin{array}{l}\text { Private } \\
\text { reserve }\end{array}$ & Yes & None & 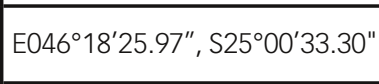 \\
\hline $\begin{array}{c}\text { Emikaina } \\
\text { Mahialambo }\end{array}$ & $10 / 04 / 2015$ & 0 & 0.3 & $\begin{array}{l}\text { Eucalyptus } \\
\text { plantation }\end{array}$ & - & - & E0470' $49.75^{\prime \prime}, \mathrm{S} 24^{\circ} 53^{\prime} 55.50^{\prime \prime}$ \\
\hline $\begin{array}{c}\text { Enato } \\
\text { Anandrano }\end{array}$ & 09/22/2015 & 0 & 2.68 & Sacred forest & - & - & E046⒌'35.66", S245ㄷ'04.69" \\
\hline Ivolo & $10 / 03 / 2015$ & $560 \pm 10$ & 8.36 & $\begin{array}{l}\text { Eucalyptus } \\
\text { plantation }\end{array}$ & No & Logging & E046 $55^{\prime} 05.09^{\prime \prime}, \mathrm{S} 24^{\circ} 55^{\prime} 35.33^{\prime \prime}$ \\
\hline Manambaro & $10 / 13 / 2015$ & $290 \pm 20$ & 155 & Niaouli stand & No & Logging & E04650'57.23", S2500'51.86" \\
\hline Mandena & $10 / 12 / 2015$ & $300 \pm 20$ & 85.1 & Niaouli stand & Yes & $\begin{array}{l}\text { Mining } \\
\text { activity }\end{array}$ & E04701'37.70", S2458'04.31" \\
\hline Sainte Luce & 10/07/2015 & $130 \pm 5$ & 382 & Littoral forest & No & Deforestation & E0470'ㄴ․ $26.16^{\prime \prime}, \mathrm{S} 24^{\circ} 48^{\prime} 41.92^{\prime \prime}$ \\
\hline Volombe & 10/11/2015 & $60 \pm 5$ & 1.88 & Sacred forest & Yes & Disturbance & E047 $05^{\prime} 37.07^{\prime \prime}, \mathrm{S} 24^{\circ} 41^{\prime} 16.19^{\prime \prime}$ \\
\hline
\end{tabular}


bats, representing a positive difference of some $25 \%$. Elsewhere two of the surveyed colonies have shown no significant change when compared to the data available from a decade ago (Analalava and Volombe), with both roosts supporting a very similar number of bats as in 2006. Finally, alongside the two colonies that could no longer be located (Emikaina Mahialambo and Enato Anandrano), a large negative difference can be seen in the number of bats observed now at Amborabao (338), compared with the number of individuals in 2006 (412), a reduction of 18\%.

The large colony observed at Ivolo represents a significant proportion of the flying foxes in the region, yet the true extent of the colonies size here remains unverified. Although we observed a large group of approximately 560 bats, the local chef de fokontany explained that this was merely half of the full colony. The previous estimate presented in Jenkins et al. (2007) also suggests that two groups are present here, and that the combined total in 2006 was circa 1000 bats. However we could gather no further evidence to support the presence of a second large group of bats over the course of our several hour roost visit. It is possible however that a secondary roost does exist out of sight in this mountainous region, although we did not make a single aerial observation to indicate the presence of a nearby secondary roost or recently disturbed group.

The average colony size for the region stands at 498 bats per roost, notably higher than the national average of 400 (Mackinnon et al. 2003). However it is clear that the colony at Berenty influences this result due to its relatively large size, and if excluded the average colony size drops to just 259 bats per roost. Given the lack of directly comparable data between our study and the data available from 2006, only an approximate indication of general trend can be extracted. Of the ten colonies identified in this study and the nine assessed in 2006, only four of the roosts are suitable for direct comparisons (Amborabao, Analalava, Sainte Luce and Volombe). Earlier datasets are available for the Berenty colony dating from between 1996 and 1999 (Long and Racey 2007).

When assessed together, the relatively small and unprotected roosts appear to now support $8 \%$ fewer bats than a decade ago whereas the data available for Berenty suggests that this colony supported some $8.25 \%$ more bats in 2013 than it did in 1999 (Long and Racey 2007). Assuming that this increase has been linear, based on the relatively stable conditions at the roost, we estimate the colony at Berenty to have supported approximately 2070 in 2006. Once this inferred Berenty data are also figured into the calculation, the overall abundance of bats in our study area can be seen to have increased by $1.25 \%$ between 2005/6 and $2015 / 6$. This calculation is based using the upper abundance estimates offered in Jenkins et al. (2007) and Long and Racey (2007). The modern figures are based solely on the number of bats observed during our assessment, and do not include population estimates based on community opinion.

The remaining five colonies were excluded from comparison as four of the roosts; Emikaina Mahialambo, Enato Anandrano, Manambaro and Mandena lacked the requisite datasets. In the case of the Ivolo colony, the large unknown error margin in abundance made it inappropriate for comparisons to be drawn. However it is important and perhaps just as useful to consider the health and status of each colony individually as each colony is subject to a specific set of circumstances. Also given the difficulties associated with comparing and making generalizations regarding the total population present in the southeastern Anosy
Region, further information pertaining to each colony's individual status is presented in the following. Further details of the communities' attitude towards local roosts and our survey methods and techniques at each site are also included.

AMBORABAO (FARAFARA-VATEMBY). The well-known colony exists in a very small $(<5$ ha) remnant of humid forest (altitude $148 \mathrm{~m}$ ), and our survey counted 338 bats. Local fady protects the forest patch, as it is the sacred site of an ancestral tomb. Despite this the colony has declined over the past ten years. Previous counts indicated that some 412 bats once occupied this roost (Jenkins et al. 2007a), however the small size of the forest fragment and lack of suitable roosting branches may be restricting the colony. Our SEED Madagascar (local NGO) community agent and local chef de fokontany suggest that the population is currently increasing indicating that bat numbers declined since the 2006 count. The primary roost itself is spread across several levels and multiple trees including voapaky (Uapaca spp. Euphorbiaceae), fotsivavo (unidentified species, Annonaceae) and tavolo (Cryptocarya acuminata Lauraceae). Average canopy height is around $15 \mathrm{~m}$ in the fragment interior. Hunting is known to take place at feeding sites, particularly during the lychee season. Damage to the patagia of many bats was observed, which could be the result of slingshot. The bats are respected to an extent and do infrequently bring in income to the remote community as passing tourists can pay to visit the roost, however they are also viewed as pests which maraud fruit trees. Disturbance is a major threat to this colony (Figure 2), as the roost is surrounded by agricultural land, and situated near a busy community pathway. Regular disturbance causes the entire colony to take flight to another forest fragment some 700m southwest and our survey coincided with such an event, allowing for a straightforward and accurate census.

ANALALAVA (ANTRANOPANIHY). This unprotected parcel of littoral forest is relatively isolated, situated on a small island cut off by the arms of an estuary (Asihanaky), making it accessible only by pirogue. The forest and roost are ca. $3.6 \mathrm{~km}$ from the nearest village, Ambanihazo and at an altitude of just $15 \mathrm{~m}$. Our colony

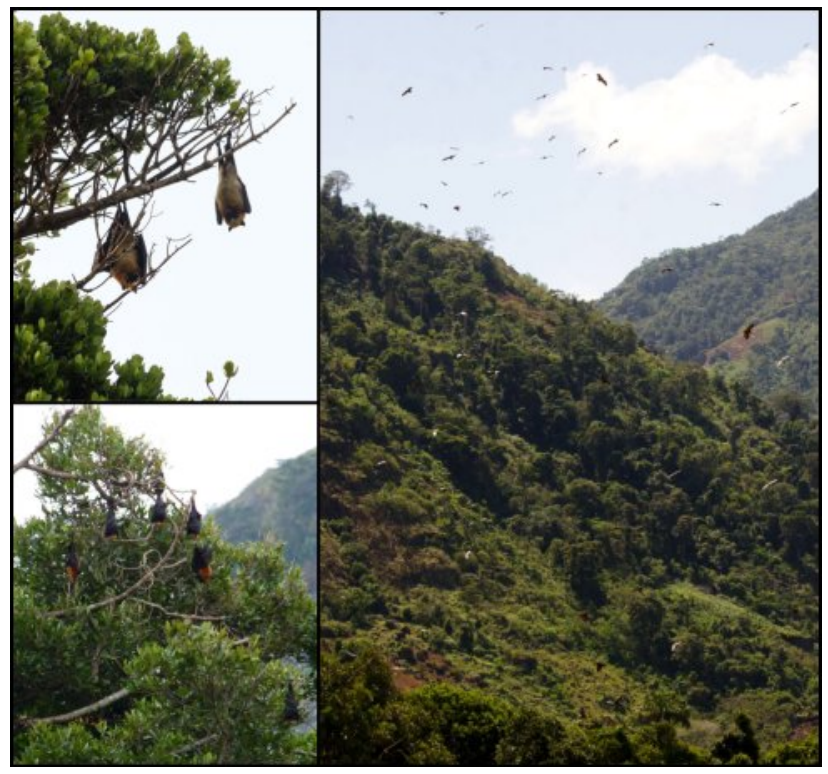

Figure 2. Roosting and disturbed Madagascan flying foxes (Pteropus rufus) at the Amborabao colony, assessed during this study (September 2015). Photographic credits: M. Darling and S. Long. 
count of 140 individuals is similar to that previously made in 2006, of 150 bats. Our local FIMPIA representative and guide disclosed that hunting for bushmeat is common in the area and that bats are also killed to protect valuable fruit crops. Again during our surveys we observed bats with damage to their patagia, and again we were told that slingshots are the most common form of hunting, with guns now rare. Despite this the roost itself is protected by FIMPIA, meaning that hunting of bats occurs away from the roost. We were informed that the population at this site was once very large and supported over 1000 bats, but due to excessive and unsustainable hunting numbers have been greatly diminished.

During our survey visit we found evidence that both logging and tavy is practiced close to the roost site, and trees had been felled just several meters away from the main roost trees. Evidence from recent and extensive fires demarcated the forest boundary, and the interior is highly degraded secondary forest. The roost itself exists at two proximal locations within the same forest, and we were able to conduct the count as the bats moved between the two sites just prior to dusk. The average forest canopy height is around $15 \mathrm{~m}$ and notable roosting trees include both fatsikahitra (Canephora madagascariensis Rubiaceae) and voatsimatra (Salacia madagascariensis Celastraceae).

BERENTY PRIVATE RESERVE. The bat population at Berenty Private Reserve is the largest known in the region, with a total of 2160 reported from the last census conducted in 2013. The population here is spread over five closely adjoined roosting sites, all centered on and around mature tamarind (Tamarindus indica Fabaceae) trees, with nearby acacia (Acacia rovumae Fabaceae) and fig trees (Ficus spp. Moraceae) providing additional roosting capacity. All roosting sites within the gallery forest reserve are strictly protected from both hunting and disturbance, with tourists also being prohibited from approaching within 70m. However it is known that hunting does still occur at feeding sites outside of the reserve (J. P. Seccaldu, pers. comm., October 2015). The colony has expanded rapidly since the 2011 count when it consisted of approximately 1800 individuals. Previously hunting for bushmeat was known to occur outside of the reserve at the bat feeding grounds, however this also seems to have been curtailed as of 2010 as a result of education and pressure from the reserve management.

EMIKAINA MAHIALAMBO (EKAIMBE). We were unable to locate this colony of flying foxes during our study and we believe that the population has relocated, merged with a nearby coIony or has been extirpated. Jenkins et al. (2007) reported that the colony consisted of around 100 bats and these were at the time subject to hunting with guns. At the time of our visit, the eucalyptus plantation (a mixture of Corymbia citriodora Myrtaceae, Eucalyptus camaldulensis and E. robusta Myrtaceae) had been cut down and no evidence of a roost remained. Local community members and the chef de fokontany of Mahialamba and chef of FIMPIA both suggested an alternative site (E047 ${ }^{\circ} 3^{\prime} 49.7^{\prime \prime}$ ', S24 $53^{\prime}$ 55. 50") where bats had been seen roosting more recently, however this small and exposed eucalyptus plantation had also been abandoned. The colony had last been observed there in May 2015, and was estimated to have consisted of around 80 bats. However the barren landscape had been subjected to large fires and a severe windy period in September 2015. The site was also unprotected and the plantation open for unrestricted resource use, although the area is not particularly accessible with the nearest village (Mandromoromotra) almost $5 \mathrm{~km}$ away.

ENATO ANANDRANO. As with the previous roost, we were unable to locate this colony. Satellite imagery obtained from Google Earth (2012) revealed that the lowland rainforest location, reported by Bollen and Elsacker (2002) and cited by Jenkins et al. (2007), had since been completely cleared. We were further informed by members of the local community that the bat roost had subsequently moved to a small sacred forest stand, just 550m from the village up until 2010. During this time the bats had been protected by fady although the high level of disturbance would have made this location difficult for the bats in the long-term. A combination of agricultural encroachment, human disturbance, persecution at feeding sites and less than three hectares of forest is likely to have forced the colony to either relocate or disperse. The abandoned roost tree was confirmed as haramry, a vernacular name we could not associate with a Latin binomial. Community members insist that bats still forage in the village at night on Ficus spp. indicating that a roost may still be present in the foothills of Enato Anandrano. The landowner, whose site protected the bat roost until 2010, estimated that the colony contained around 300 bats before leaving the area.

IVOLO. The Ivolo colony is thought to consist of two large groups of flying foxes roosting in a privately owned and regulated mature eucalyptus (Corymbia citriodora) plantation. The plantation is approximately 50 years old and on reaching maturity is now subject to intensive logging and reclamation. Our colony count of approximately 560 individuals was carried out with a clear line of sight and therefore a high degree of accuracy. However the chef de fokontany of Ivolo informed us that an hour before our arrival, a man armed with a small firearm had attempted to poach bats, and in the process had disturbed one large group. We were informed that the group that had been disturbed was equal to the size of the group that remained. If true, the total population would be around 1120 - similar to that reported in 2007 (Jenkins et al. 2007a). However, we can only confirm the presence of 560 bats with any certainty.

The bats here are afforded no protection, and the logging is indiscriminate of roost, with trees being felled close to the roost trees. Similarly, poaching seems to occur at the roost site, and we were informed that hunting both for meat and pest control is common. Whilst hunting bats at their roost site is considered illegal here, the law is not enforced, and away from the roost site legal hunting involves netting at fruiting lychee and mango trees. As the plantation covers approximately 10 hectares, with all the eucalypts of equal age and height (20-22m), the colony seem to be able to settle anywhere within its boundaries. There is also a small sacred forest area near the village that is also frequented by the bats, where protection is afforded through taboo (fady). With the disturbed bats elsewhere for several hours during our survey, there may also be another roost site at higher altitude in the mountain foothills.

MANAMBARO. A large stand of fast growing and non-native niaouli (Melaleuca quinquenervia and $M$. leucadendra Myrtaceae) trees ca. $12 \mathrm{~km}$ outside of Fort Dauphin (Tolagnaro) supports a colony of around 285-300 bats. This roost site has never been reported to the best of our knowledge yet is thought to have been 
established at this location for the past 20 years. The plantation covers ca. 155 hectares and supports the local communities of Magnavara and Nosy Be, being used primarily for firewood, charcoal and brick manufacture. The colony here is extremely sensitive and we were informed that this population is commonly hunted for bushmeat, with slingshot being the principal hunting technique. The swampy nature of the area offers a modicum of protection for the roost, but busy rice paddies surround the plantation margins. Large declines are thought to have occurred over the past two decades and the roosts close proximity of the roost to Fort Dauphin and the good transport infrastructure make the roost more vulnerable. The bats use the emergent trees to roost, which stand at approximately $12 \mathrm{~m}$, two meters above the majority of the monoculture. This allowed for a relatively straightforward visual census from a medium distance, although some bats may have been obscured.

MANDENA. A newly formed roost on the southern outskirts of the QMM / RioTinto mining site, is thought to have been established within the past two years. The introduced species of niaouli stand covers approximately 100 hectares of riverine and swamp habitat in the area. The roost is protected by its inaccessible location and the restricted public access offered by the mine. The canopy height here is around 10m on average, with bats favoring emergent trees of around $12 \mathrm{~m}$ in which to roost. Our survey was made from a boat positioned in the estuary, and we were able to observe what seemed to be the entire colony fly over the water body to a secondary roost site, and then back. The flight was filmed and analysed using Final Cut Pro to obtain an accurate count although we could not be certain that the entire colony took flight.

SAINTE LUCE. This roost is currently situated in the forest fragment $\mathrm{S} 6$ but has previously been cited as existing in S7 (see Figure 1 in Lowry et al. 2008), a twin fragment laying parallel and only separated by a thin ribbon of swamp. Together these two forest fragments make up approximately 382 hectares of original littoral forest, making them one of the largest remaining patches of this lowland forest habitat in existence. This roost was first reported in 1992 by Lewis Environmental Consultants, as part of the QIT Madagascar Minerals Project (Lewis Environmental Consultants 1992) who reported a large colony of some 300 individual bats. Repeat visits to the roost and multiple counts over the course of 2015 enabled us to make a confident estimate of the colonies current size, at around 130 individuals. It is apparent that this roost was once considerably larger, with Bollen and Elsacker (2002) reporting between 300 and 350 bats still in 2000 but Jenkins et al. (2007) reported just 104 bats in 2006. The forest here is currently open to unrestricted community resource use and vulnerable to outside exploitation. Further, it is experiencing a high level of degradation and the roost sites are threatened by logging. However the NGO SEED Madagascar is currently engaged in a community project aiming to safeguard the colony and hopes to secure its long-term presence in the area.

The colony is known to occupy two roost sites in S6, and currently none are known from within S7. All previously cited coordinates in S7 were investigated but no further evidence of bat occupancy was found, only evidence of extensive logging. Given the similarity between the colony size previously reported in S7 in 2002 , we infer that the population is likely to have simply changed locations and now resides in S6. The primary roost site now consists of a small cluster of tall hazomainty (Diospyros spp. Ebenaceae) trees (approximately 25-26m), with branched evergreen crowns. Other trees frequently used as part of the secondary roost include hazondroka (unknown vernacular name), nato (unknown spp. Sapotaceae) and fantsikaidroka (Pseudopeponidium asosa Rubiaceae). The bats in this population are extremely sensitive and wary of humans, and several individuals were seen with observable damage to their patagia. Evidence of logging is clear at both roost sites and the colony is threatened by continual logging. Similarly, low-level tourism occurs at this roost site, with a nearby eco-lodge offering its cliental the opportunity to visit the roost, as well as monthly visits made by researchers and volunteers from local NGO SEED Madagascar.

VOLOMBE. A small colony consisting of some 60-65 bats, situated in a tiny fragment of sacred forest near the remote community of Androtsy Antanadava. The colony is believed to have once been very large and has been present in the area for the past 40 years, but was recently displaced from a nearby forest (Andranopanihy) which was clear felled. The roost site is supposedly protected by fady, although the bats are hunted with both nets and firearms at their feeding grounds; our guide was informed that occasional hunting also occurs within the sacred forest. The landscape is dotted with small remnants of forest protected as sacred tomb sites, yet the small size of this colony suggests that consistent hunting and persecution is prevalent. The extent of the roost site is less than two hectares and encircled by agricultural plots, yet potentially viable habitat still remains on the nearby hills only a few kilometers away. The roost here is spread across multiple tree species, but most notable are varongy trees (Rhus taratana Anacardiaceae).

\section{DISCUSSION}

Given the high level of deforestation and habitat fragmentation in Madagascar (Goodman and Benstead 2003, Harper et al. 2007, Temple et al. 2012), the protection of endemic and ecologically important species should be considered amongst the highest priorities. The established capacity of this mainly frugivorous species for long distance seed dispersal, pollination and the positive effects of passage of seeds through the gut on germination (Bollen and Elsacker 2002, Racey et al. 2010, Oleksy 2012, Oleksy et al. 2015), should make it a highly desirable species in areas striving to sustain their natural environments. The highly fragmented forests of the southeast appear now to depend on the abilities of such species as the flying fox if they are ever to recover to a state where ecosystems function effectively and continue to support the high levels of species richness and biodiversity previously observed (Ganzhorn and Goodman 2007). With evidence suggesting that the ecosystem services provided by bats are significantly diminished as their populations decline (McConkey and Drake 2006), a concerted effort to safeguard the species and encourage population growth should be compelling and a cornerstone of any serious conservation strategy.

Colonies of Pteropus rufus can attain sizes of up to 5,000 individual bats (Mackinnon et al. 2003), which places into perspective the small magnitude and vulnerability of the majority of existing roosts in the Anosy Region. With many populations now existing at such low levels, the time necessary for small colonies to grow in size will be extensive especially given the species pro- 
duces a single young annually, and only occasionally twins (Mackinnon et al. 2003). The smaller the population, the more protracted the recovery or growth will be, and the more important each individual within the colony becomes. Alongside what is known about the reproductive character of the Pteropodidae in general (Hayssen et al. 1993) a further understanding of details such as lifespan in the wild and colony sex ratio will require verification before predictions of temporal population growth can be confidently proposed. The population growth seen in the colony at Berenty Private Reserve over recent times offers cause for optimism and supports a theory that given adequate protection and respect, this species can rebound. However the Berenty colony was large to begin with, and the rapid growth is likely to be proportional to the colony's initial size.

The study area clearly still supports a significant number of bats distributed across several colonies, with colony density here appearing to now approximate the levels seen in the northwest and central west lowlands (Mackinnon et al. 2003). However this study only offers a snapshot of the colony size at a single particular time, and cannot therefore offer any insight into the fluctuations occurring over the intervening years and months. Furthermore the study only includes roosts of which we are aware of, and it is quite possible that further colonies exist further inland or at higher altitudes in the Anosyenne Mountains, where potential habitat, albeit at higher elevation still remains. It is also important to stress that our study only provides data in the form of single point counts, and past research at Berenty has shown major fluctuations in colony size seasonally (Long and Racey 2007) irrespective of hunting and disturbance. Such large-scale seasonal variation in abundance indicates that certain large roosts like Berenty may be acting as central colonies, with bats seasonally dispersing in the wet season to smaller satellite colonies, before returning in the dry season.

Presently it is unclear where these missing bats go when they leave the Berenty roost, but it is known that this species can cover large distances whilst foraging (Oleksy et al. 2015), raising the possibility that bats from Berenty join the other colonies reported in this study during the rainy season, despite the nearest roost site in the study being ca. $55 \mathrm{~km}$ away. Similarly, other bat roosts are thought to exist to the northwest of Berenty, in the Androy Region but have never been located (Paul A. Racey, pers. comm., January 2016). This dispersal event also appears to coincide with the bats breeding season (Mackinnon et al. 2003), and may be a means of ensuring that high levels of genetic heterogeneity are preserved across the colonies. Other species of pteropodid bat elsewhere have been observed flying far greater distances so it is certainly a possibility (Epstein et al. 2009). If this were the case it could mean that Pteropus rufus populations are very large, and similar to Rousettus madagascariensis and $P$. niger in Mauritius, could extend panmictically across a regional or even national scale (Goodman et al. 2010, Larsen et al. 2014). Importantly our study was conducted at a time corresponding with a period when bat abundance is highest in Berenty (Long and Racey 2007), suggesting that the bat counts across the other roost sites are not inflated by supplementation from the Berenty colony and represent the true abundance at each colony. The large variation in colony size described by Long and Racey (2007) at Berenty emphasises the importance of timing when surveying and monitoring P. rufus colonies.
Our results confirm that the species maintains a high degree of roost fidelity if unmolested, with most of the colonies still present in the same or adjacent locations over a decade on. The colony at Manambaro is thought to have persisted in the same location for over 20 years (Jean Nascisse Ralaifiany, pers. comm., October 2015) whereas the colony in Sainte Luce is known to have been present in the vicinity since at least the late 1980s (Lewis Environmental Consultants 1992). This also suggests that serious threats must have been faced by the colonies at Enato Anandrano and Emikaina Mahialambo to cause their disappearance. The colony at Mahialambo was previously known to sustain losses through the use of firearms (Jenkins et al. 2007a) and any escalation could have resulted in roost abandonment. It is possible that the new roost at Mandena mine consists of bats that migrated from either or both of the lost roosts at Enato Anandrano or Emikaina Mahialambo. The short distance between the three sites (Enato-Mandena 6.5km, Emikaina-Mandena $8.6 \mathrm{~km}$ ) would have made for a relatively easy journey given the long distances the species is capable of flying (Racey et al. 2010, Oleksy et al. 2015).

The small size and lack of growth observed at the majority of the roosts assessed in this study indicates that the flying foxes in the region remain under pressure. However the fact that the average colony size remains broadly consistent with the findings of Mackinnon et al. (2003) highlights this specie's resilience being able to tolerate small forest patches near to human settlements, to use both native and introduced tree species as suitable roosts and even relocate roost site. Currently only one of the ten roost sites is afforded effective and long-lasting protection (Berenty), whilst the colony at Mandena is secure only on the grounds that it resides on private land. Fortunately the colony here exists outside of the proposed mining zone, however in decades to come once the mine is closed, the plantation will likely be in great demand. Of the remaining six extant roosts only two are quasi-protected by occupying 'sacred forests' or the sites of ancestral family forest tombs (Amborabao and Volombe). However both of these roosts are precariously enduring in tiny forest remnants, making them vulnerable to perturbation by disturbance, exploitation or loss of roosting habitat. In the case of the colony at Enato Anandrano, the sacred forest we visited where the previous roost had been abandoned, we saw clear signs of logging and severe agricultural encroachment. These same practices were also manifest at the roost sites at Amborabao and Volombe, and their long-term futures must be considered as imperiled. It is clear that fady has played an important role in protecting wildlife in the past, but modern pressures are slowly eroding traditionally maintained practices, and the protection taboo offers to wildlife can no longer be taken for granted.

The two roosts occupying littoral forest fragments at Analalava and Sainte Luce represent the only two colonies in the study besides Berenty to roost in natural forests. These littoral forest fragments have been substantially reduced in size and degraded over time, and now exist only as a series of disconnected remnants (Bollen and Elsacker 2002, Ganzhorn and Goodman 2007, Temple et al. 2012). The prevailing pattern of deforestation and littoral forest loss continues and significant future losses are predicted, particularly in Sainte Luce (Temple et al. 2012). The bats roosting at these fragments have easy access to a large variety of endemic food items, and a dietary study between 1999 and 2001 indirectly observed the bats at Sainte Luce feeding and dispersing 
the seeds of 40 fruit species (28 genera, 21 families) (Bollen and Elsacker 2002). Similarly Racey et al. (2010) reported that the diet of this species seems highly adaptable and varies geographically, depending on locally available resources. The bats dual capacity for long distance seed dispersal and pollination is vital for ensuring the genetic heterogeneity and diversity is maintained between plant communities of different and isolated forest fragments, and vital for any future forest expansion and regeneration.

The flying fox population at Sainte Luce has clearly fluctuated over recent times, but has seemingly increased steadily since 2006. Prior to this, the colony was known to have experienced intense harvesting and stood at between 300-350 individuals in 2001 (Bollen and Elsacker 2002). The forest fragment in which the colony resides, $\mathbf{S 6}$ has been reduced by some 63 hectares since 2001 and is currently exposed to heavy degradation. Forest loss in Analalava are less well documented but it seems the bat population increased between 2001 and 2006, from around 50 bats to between 100 and 150 individuals, a total which our study has found is accurate still today. Currently both the Analalava and Sainte Luce colonies are under intense pressure from unregulated logging, hunting and the various aspects of anthropogenic disturbance. Although we saw multiple individuals with damage to their patagia at both roost sites, this cannot be definitively attributed to hunting practices, as it is also known to occur naturally as a result of mis-navigation and even aggressive interaction (Paul A. Racey, pers. comm., January 2016). Arguably however these two colonies represent two of the most valuable roosts observed in the study, and future conservation work should focus on their protection. Individuals from these roosts are likely to disperse the largest variety of native seeds on a regular basis, due to their natural diet and ease at which they can acquire fruits and berries. They also are more likely to move between patches of natural forest most frequently due to the position of their home roosts, meaning their dispersal of seeds could contribute significantly to the regeneration of littoral forests (Bollen and Elsacker 2002).

These two littoral forest roosts are threatened primarily by deforestation and the loss of suitable roosting habitat. The twin forest fragments S6 and S7 in Sainte Luce presently provide sufficient habitat and refuge, however recent political and forest resource use reforms now permit unregulated access and wood collection in these forest fragments and extensive logging is underway. These fragments now solely support multiple local communities and supply external timber merchants without regulation since the recent protection (Système des Aires Protégées de Madagascar status) offered to nearby fragments S8 and S9 (NAP Ambatoatsinana decree N. 2015-778). This management system needs urgent revision if the bats and local human communities are to prevail in forthcoming decades, however the bats would gain protection if they were to move to one of the newly protected sites. The Analalava colony receives slightly better protection due to the difficult access and isolated nature of the forest; however during our visit we saw evidence of extensive fire damage and logging on the forests boundaries, as slash and burn agriculture (tavy) encroaches nearer to the roost. With the national policy currently dedicated to tripling the area protected across Madagascar (Andriafidison et al. 2008), threatened littoral forest habitats that are known to support exceptionally high levels of biodiversity and include bat roosts should be considered strong candidates.
Elsewhere, the roost at Manambaro seems fairly secure, situated in an expanding niaouli stand spread over some 155 hectares of swampy ground. Accurate historical population data for the colony is not known to exist however local community members agree that the colony was at one time a lot larger. The proximity of this non-endemic forest to the larger human populations and the city of Tolagnaro makes it vulnerable to rapid consumption and exploitation if permissions around resource use were to change. Similarly the large private eucalyptus plantation at Ivolo is susceptible to extensive felling given any changes to management policy, particularly as the plantation has now reached maturity making the estate a valuable resource. Such economic pressures make the colonies vulnerable to displacement, yet their continued presence underlines the remarkable adaptability of Pteropus rufus in terms of habitat type and quality, and the degree of disturbance it can tolerate (Mackinnon et al. 2003, Jenkins et al. 2007a). Our observations have shown that across the ten roosts included in the study, 13 species of tree have been utilized as main roost sites, including three notable introduced species, Corymbia citriodora, Melaleuca quinquenervia and Tamarindus indica, but these account for $50 \%$ of the colonies primary roosting trees. The high proportion of introduced tree species acting as alternatives for native and endemic species, perhaps suggests a lack of suitably large and mature native trees in many areas. Our results also reinforce the importance of small forest patches and sacred forests for the persistence and preservation of flying fox colonies across a highly modified and fragmented landscape (Jenkins et al. 2007a, Andriafidison et al. 2008, Racey et al. 2010).

It is our hope that the information outlined here, alongside the previous work of Jenkins et al. (2007), can contribute towards future flying fox monitoring in the region and stimulate the establishment of long term conservation projects to protect these ecologically important species. We echo the need for communityled conservation programmes to boost the number of bats present within small and vulnerable colonies, and to work towards the long term protection of both roost and feeding sites (Jenkins et al. 2007a, Jenkins and Racey 2008, Racey et al. 2010). A nationwide strategy for improving education with regards to bat conservation is now required to halt the declines seen over recent years and to propagate knowledge of the recent 2007 law amendments. The importance of bats as a valuable source of meat should also be considered on a localized scale, with any sustainable community harvest quotas set against the background of local bat population declines and pressures from expanding human communities (Mildenstein et al. 2016). Similarly the impacts associated with increased bat numbers such as increased interference of fruit crops should be estimated, offset, and included in carefully considered conservation management schemes (Abdul Azis et al. 2016). This review will hopefully set a useful marker for future Pteropus rufus monitoring in the southeastern Anosy Region and provide indirect data as to the effectiveness of the 2007 hunting decree.

\section{ACKNOWLEDGEMENTS}

We thank all of those who have contributed towards this work, and especially to both Ralaitiany Jean Narcisse and Jean Philipe seccaldu whose knowledge, enthusiasm and passion for conservation have played such an important part in this project. Our gratitude also to all of the community members who have been so hospitable and congenial during our visits, and for granting us the 
requisite authority to access such restricted and sacred locations. A special thanks to Paul Racey, whose insights and advice have helped develop this work. Finally we wish to acknowledge all of the SEED Madagascar team who endeavor behind the scenes to improve the future for people and wildlife in Sainte Luce and the wider Anosy region.

\section{REFERENCES}

Abdul Aziz, S., Olival, K. J., Bumrungsri, S., Richards, G. C. and Racey, P. A. 2016. The conflict between fruit bats and fruit growers: species, legislation and mitigation. In: Bats in the Anthropocene: Conservation of Bats in a changing World. C. C Voigt and T. Kingston (eds.), pp 377-426. Springer, New York.

Andriafidison. D., Andrianaivoarivelo, R. A., Ramilijaona, O. R., Razanahoera, M. R., Mackinnon, J., Jenkins, R. K. B. and Racey, P. A. 2006. Nectarivory by endemic Malagasy fruit bats during the dry season. Biotropica 38, 1: 85-90. (doi:10.1111/j.1744-7429.2006.00112.x)

Andriafidison, D., Cardiff, S.G., Goodman, S. M., Hutson, A. M., Jenkins, R. K. B., Kofoky, A. F., Rabearivelo, A., Racey, P. A., Ranivo, J., Ratrimomanarivo, F. H. and Razafimanahaka, H. J. 2008. Eidolon dupreanum, Pteropus rufus \& Rousettus madagascariensis. The IUCN Red List of Threatened Species 2008: <http://dx.doi.org/10.2305/IUCN.UK.2008.RLTS.T18756A8568476.en> downloaded 21 January 2016.

Andrianaivoarivelo, R. A., Andriafidison, D., Rahaingonirina, C., Raharimbola, S., Rakotoarivelo, A. A., Ramilijaona, O. R., Racey, P. A. and Jenkins, R. K. B. 2011. A conservation assessment of Rousettus madagascariensis (G. Grandidier, 1928, Pteropodidae) roosts in eastern Madagascar. Madagascar Conservation \& Development 6, 2: 78-82. (doi:10.4314/mcd.v6i2.6)

Bollen, A. 2008. Fruit characteristics: Fruit selection, animal seed dispersal and conservation matters in the Sainte Luce forests. Ecology and conservation of bats in the southern Anosy Region. In: Biodiversity, Ecology and Conservation of Littoral Ecosystems in Southeastern Madagascar, Tolagnaro (Fort Dauphin). J. U. Ganzhorn., S. M. Goodman and M. Vincelette (eds.), pp 127-146. SI/MAB Series No. 11. Smithsonian Institution, Washington, DC.

Bollen, A. and Donati, G. 2005. Phenology of the Littoral Forest of Sainte Luce, Southeastern Madagascar. Biotropica 37, 1: 32-43. (doi:10.1111/j.17447429.2005.04094.X)

Bollen, A. and Donati, G. 2006. Conservation status of the Littoral Forest of southeastern Madagascar: A review. Oryx 40, 1: 57-66. (doi:10.1017/S0030605306000111)

Bollen, A. and Elsacker, L.V. 2002. Feeding Ecology of Pteropus rufus (Pteropodidae) in the Littoral Forest of Sainte Luce, SE Madagascar. Acta Chiropterologica 4, 1: 33-47. (doi:10.3161/001.004.0105)

Bollen, A., Elsacker, L.V. and Ganzhorn, J. U. 2004a. Tree dispersal strategies in the littoral forest of Sainte Luce (SE-Madagascar). Community Ecology. Oecologia 139, 4: 604-616. (doi:10.1007/s00442-004-1544-0)

Bollen, A., Elsacker, L. V. and Ganzhorn, J. U. 2004b. Relations between fruits and disperser assemblages in a Malagasy littoral forest: a community-level approach. Journal of Tropical Ecology 20, 6: 599-612. (doi:10.1017/S0266467404001853)

Consiglio, T., Schatz, G. E., Mcpherson, G., Lowry, P. P., Rabenantoandro. J., Rogers, Z. S. and Rabehevitra, D. 2006. Deforestation and plant diversity of Madagascar's littoral forests. Conservation Biology 20, 6: 1799-1803. (doi:10.1111/j.1523-1739.2006.00562.x)

Durbin, J. 2007. New legislation for the protection of Malagasy species. Lemur News 12: 4-6.

Ganzhorn, J. U., Goodman, S. M. and Vincelette, M. (eds.) 2007. Biodiversity, Ecology and Conservation of Littoral Ecosystems in Southeastern Madagascar, Tolagnaro (Fort Dauphin). SI/MAB Series No. 11. Smithsonian Institution, Washington, DC.

Goodman, S. M. and Benstead, J. P. 2003. Natural History of Madagascar. The University of Chicago Press, Chicago.

Goodman, S. M., Andriafidison, D., Andrianaivoarivelo, R., Cardiff, S. G., Ifticene, E. et al. 2005. The distribution and conservation of bats in the dry regions of Madagascar. Animal Conservation 8, 2: 153-165. (doi:10.1017/S136794300500199X)
Goodman, S. M., Chan, L. M., Nowak, M. D. and Yoder, A. D. 2010. Phylogeny and biogeography of western Indian Ocean Rousettus (Chiroptera: Pteropodidae). Journal of Mammalogy 91, 3: 593-606. (doi:10.1644/09-MAMM-A283.1)

Harper, G. J., Steininger, M. K., Tucker, C. J., Juhn, D. and Hawkins, F. 2007. Fifty years of deforestation and forest fragmentation in Madagascar. Environmental Conservation 34, 4: 1-9. (doi:10.1017/S0376892907004262)

Hayssen, V. 1993. Empirical and theoretical constraints on the evolution of lactation. Journal of Dairy Science 76, 10: 3213-3233.

Hayssen, V., van Tienhoven, A. and van Tienhoven, A. 1993. Asdell's Patterns of Mammalian Reproduction: A Compendium of Species-Specific Data, revised second edition. Cornell University Press, Ithaca, NY.

Jenkins, R. K. B. and Racey, P. A. 2008. Bats as bushmeat in Madagascar. Madagascar Conservation \& Development 3, 1: 22-30. (doi:10.4314/mcd.v3i1.44132)

Jenkins, R. K. B. and Tatayah, V. 2009. Observations, discussions and updates. Flying foxes (Pteropodidae: Pteropus) in the Western Indian Ocean: A regional initiative. African Bat Conservation News 21: 2-3.

Jenkins, R. K. B., Kofoky, A. F., Russ, J. M., Andriafidison, D., Siemers, B. M. et al. 2007a. Ecology and conservation of bats in the southern Anosy Region. In: Biodiversity, Ecology and Conservation of Littoral Ecosystems in Southeastern Madagascar, Tolagnaro (Fort Dauphin). J. U. Ganzhorn, S. M. Goodman and M. Vincelette (eds.), pp 209-222. SI/MAB Series No. 11. Smithsonian Institution, Washington, DC.

Jenkins, R. K. B., Andriafidison, D., Razafimanahaka, J. H., Rabearivelo, A., Razafindakoto, N. et al. 2007b. Not rare, but threatened: the endemic Madagascar flying fox Pteropus rufus in a fragmented landscape. Oryx 41, 2: 263-271. (doi:10.1017/S0030605307001883)

Jones, J. P. G., Andriamarovololona, M. M. and Hockley, N. 2008. The importance of taboos and social norms to conservation in Madagascar. Conservation Biology 22, 4: 976-986. (doi:10.1111/j.1523-1739.2008.00970.x)

Jones, G., Shilton, D. S., Kunz, T. H., Willig, M. R. and Racey, P. A. 2009. Carpe noctem: The importance of bats as bioindicators. Endangered Species Research 8: 93-115. (doi:10.3354/esr00182)

Kofoky, A., Andriafidison, D., Ratrimomanarivo, F., Razafimanahaka, H. J., Rakotondravony, D., Racey, P. A. and Jenkins, R. K. B. 2006. Habitat use, roost selection and conservation of bats in Tsingy de Bemaraha National Park, Madagascar. Biodiversity and Conservation 16, 4: 1039-1053. (doi:10.1007/s10531-006-9059-0)

Larsen, P. A., Hayes, C. E., Wilkins, M. A., Gomard, Y., Sookhareea, R., Yoder, A. D. and Goodman, S. M. 2014. Population genetics of the Mauritian flying fox, Pteropus niger. Acta Chiropterologica, 16, 2: 293-300. (doi:10.3161/150811014X687251)

Lewis Environmental Consultants. 1992. Madagascar Minerals Project, Environmental Impact Assessment Study. Part 1: Natural Environment. In IImenite Project. Social and Environmental Impact Assessment. Supporting Document no.5. Presented by QIT Madagascar Minerals S.A. to the Madagascar National Environment Office, May 2001.

Long, E. and Racey, P. A. 2007. An exotic plantation crop as a keystone resource for an endemic megachiropteran, Pteropus rufus, in Madagascar. Journal of Tropical Ecology 23, 4: 397-407. (doi:10.1017/S0266467407004178)

Lowry, P. P., Randriatafika, F. and Rabenantoandro, J. 2008. Conservation status of vascular plant species from the QMM / Rio Tinto mining area at Mandena, Tolagnaro (Fort Dauphin) region, southeast Madagascar. Madagascar Conservation \& Development 3, 1: 55-63. (doi:10.4314/mcd.v3i1.44137)

Mackinnon, J. L., Hawkins, C. E. and Racey, P. A. 2003. Pteropodidae, fruit bats. In: The Natural History of Madagascar. S. M. Goodman and J. P. Benstead (eds.), pp 1299-1302. The University of Chicago Press, Chicago.

McConkey, K. R. and Drake, D. R. 2006. Flying foxes cease to function as seed dispersers long before they become rare. Ecology 87, 2: 271-276. (doi:10.1890/05-0386)

Mickleburgh, S. P., Hutson, A. M. and Racey, P. A. 1992. Old World Fruit Bats - An action Plan for their Conservation. IUCN/SSC Chiroptera Specialist Group. IUCN, Gland, Switzerland. 
Mildenstein, T., Tanshi, I. and Racey, P. A. 2016 Exploitation of bats for bushmeat and medicine. In: Bats in the Anthropocene: Conservation of Bats in a Changing World. C. C. Voigt and T. Kingston (eds.), pp 325-375. Springer, New York.

Nyhagen, D. F., Turnbull, S. D., Olesen, J. M. and Jones, C. M. 2005. An investigation into the role of the Mauritian flying fox, Pteropus niger, in forest regeneration. Biological Conservation 122, 3: 491-497. (doi:10.1016/j.biocon.2004.08.012)

Oleksy, R. 2012. The contribution of fruit bats to forest regeneration in Madagascar - Do bat-processed seeds do better? Unpublished Report to The Rufford Small Grants Foundation. Available from <http://www.rufford.org/rsg/projects/ryszard_oleksy>.

Oleksy, R., Racey, P. A. and Jones, G. 2015. High resolution GPS tracking reveals habitat selection and the potential for long-distance seed dispersal by Madagascan flying foxes Pteropus rufus. Global Ecology and Conservation 3: 678-692. (doi:10.1016/j.gecco.2015.02.012)

Racey, P. A., Goodman, S. M. and Jenkins, R. K. B. 2010. The ecology and conservation of Malagasy bats. In: Island Bats: Evolution, Ecology, and Conservation. T. H. Fleming and P. A. Racey (eds.), 369-404. The University of Chicago Press, Chicago.

Rahaingodrahety, V. N., Andriafidison, D., Ratsimbazafy, J. H., Racey, P. A. and Jenkins, R. K. B. 2008. Three flying fox (Pteropodidae: Pteropus rufus) roosts, three conservation challenges in south-eastern Madagascar. Madagascar Conservation and Development 3, 1: 17-21. (doi:10.4314/mcd.v3i1.44131)

Randrianandrianina, F. H., Racey, P. A. and Jenkins, R. K. B. 2010. Hunting and consumption of mammals and birds by people in urban areas of western Madagascar. Oryx 44, 3: 411-415. (doi:10.1017/\$003060531000044X)

Randriatafika, F. and Rabenantoandro, J. 2008. Correspondance between vernacular and scientific names of littoral forest plants in the Tolagnaro area. In: Biodiversity, Ecology and Conservation of Littoral Ecosystems in Southeastern Madagascar, Tolagnaro (Fort Dauphin). J. U. Ganzhorn, S. M. Goodman and M. Vincelette (eds.), pp 209-222. SI/MAB Series No. 11. Smithsonian Institution, Washington, DC.

Razafindrakoto, N., Harwell, A. and Jenkins, R. K. B. 2010. Bats roosting in public buildings: A preliminary assessment from Moramanga, eastern Madagascar. Madagascar Conservation \& Development 5, 2: 85-88. (doi:10.4314/mcd.v5i2.63136)

Robbins, S. J. 2004. Foraging interference and fruit palatability in Pteropus scapulatus (Megachiroptera: Pteropodidae): Management implications. Unpub. Masters thesis. University of Wellington, Victoria. Available at <http://researcharchive.vuw.ac.nz/xmlui/handle/10063/166>

Shilton, L. A., Altingham, J. D., Compton, S. G. and Whittaker, R. J. 2015. Old World fruit bats can be long-distance seed dispersers through extended retention of viable seeds in the gut. Proceedings of the Royal Society of London: Biological Sciences 266, 1416: 219-223. (doi:10.1098/rspb.1999.0625)

Simmons, N. B. 2005. Order Chiroptera. In: Mammal Species of the World: A Taxonomic and Geographic Reference, Vol 1. D. E. Wilson and D. A Reeder (eds.), pp 312-529. Johns Hopkins University Press, Baltimore MD.

Temple, H. J., Anstee, S., Ekstrom, J., Pilgrim, J. D., Rabenantoandro, J. et al. 2012. Forecasting the path towards a Net Positive Impact on biodiversity for Rio Tinto QMM. IUCN and Rio Tinto Technical Series No. 2. Available at $<$ http://ow.ly/iwRt300ZFdR>

Vincelette, M., Théberge, M. and Randrihasipara, L. 2007. Evaluations of forest cover at regional and local levels in the Tolagnaro region since 1950. In: Biodiversity, Ecology and Conservation of Littoral Ecosystems in Southeastern Madagascar, Tolagnaro (Fort Dauphin). J. U. Ganzhorn, S. M. Goodman and M. Vincelette (eds.), pp 49-58. SI/MAB Series No. 11. Smithsonian Institution, Washington, DC

Wright, P. C., Tecot, S. R., Erhart, E. M., Baden, A. L., King, S. J. and Grassi, C. 2011. Frugivory in four sympatric lemurs: implications for the future of Madagascar's forests. American Journal of Primatology 73, 6: 585-602. (doi:10.1002/ajp.20936) 